\title{
Sapa Bale Batu, Batu Bale Dia": Politik Revivalisme Tradisi Siwa lima Orang “Ambon” Pasca Konflik
}

\author{
Hatib Abdul Kadir ${ }^{2}$
}

\begin{abstract}
Abstrak
Tulisan ini membahas tentang definisi siwa lima dan proses kemunculannya kembali karena dianggap mempunyai nilai pasifikasi serta rasa persatuan dalam menjaga perdamaian di Ambon pascakonflik. Redefinisi siwa lima sangatlah mendesak, mengingat pendukung kebudayaan di Pulau Ambon sangatlah beragam, terdiri beragam sub etnis dan pengguna bahasa lokal yang diketahui masih aktif sebanyak 117 dari jumlah bahasa lokal yang pernah ada kurang lebih 130-an. Disamping itu, munculnya modernitas semakin memperkuat munculnya polarisasi antara agama Islam dan Kristen yang dipeluk oleh mayoritas masingmasing sub etnis. Menghidupkan kembali siwa lima adalah sebuah proses pencarian identitas diri, mencari tahu siapa diri orang Ambon sesungguhnya, sehinggga dapat dijadikan sebagai modal sosial untuk menjali persatuan dan kebersamaan.
\end{abstract}

\section{Kata Kunci}

Tradisi, revivalisme, Ambon, siwa lima, konflik, identitas, etnis, modernitas

\section{Pendahuluan}

Pada suatu waktu hiduplah tiga bersaudara yang tingggal di bawah sebuah pohon beringin di Gunung Nunusaku. Mereka berusaha menyelamatkan diri dari datangnya banjir bandang. Setelah banjir mereda, mereka berpisah dan pergi dengan mengikuti arah cabang pohon yang ditunggangi disaat banjir. Tiga saudara laki-laki ini dipercaya sebagai nenek moyang awal di pulau Seram. Ulisiwa adalah kakak yang paling tua, Ulilima adalah kakak kedua dan Uliassa adalah yang bungsu. Keturunan dari si bungsu Uliassa hingga kini menempati beberapa wilayah di kepulauan Ambon, Haruku Saparua dan Nusalaut. Sedangkan Ulilima dan Ulisiwa tetap tinggal di Seram, kemudian dari anak pinak mereka inilah dinamakan Pata Siwa dan Pata lima, yang dimasing-masing desa pasti memiliki perserikatan ini. Keduanya hidup dalam kerjasama sosial dan ekonomi. Hingga pada akhirnya Pata Siwa lebih mengaliansikan kelompoknya pada Portugis dan masuk ke dalam sebuah agama baru bernama Kristen. Sedangkan "si adik", kelompok Pata lima memeluk agama Islam (Bartels, 2-6: 1979; 15:2003; Hulsboch 224: 2004) ${ }^{3}$.

\footnotetext{
${ }^{1}$ Istilah ini secara harfiah berarti "siapa membalikkan batu, batulah yang akan membalikkan dia" bermakna pamali atau pantangan yang menjadi tradisi orang Ambon untuk harus tetap menjaga tradisi dari orang tua kita kakek/nenek moyang. Pamali berawal dari banyaknya kasus yang terjadi karena melanggar pantangan tersebut.

${ }^{2}$ Staf pengajar antropologi di Universitas Brawijaya. Email: kedang_ori@yahoo.com

${ }^{3}$ Komposisi Pata Siwa sebagai Kristen dan Pata lima sebagai Islam ini sebenarnya agak rancu di Maluku Tengah. Karena sistem invasi kerajaan Ternate di Maluku Tengah mengubah masyarakat asli untuk masuk Islam, sedangkan Tidore cenderung membiarkan masyarakat adat untuk tetap memeluk kepercayaan adat dan agama suku bangsa mereka. Pada masa kolonial, Belanda berperang dengan Ternate, sehingga terjadi
} 
Salah satu versi lainnya misalnya, agama nunusaku adalah agama asli yang mengunifikasikan semua masyarakat di Maluku Tengah. Semenjak perang saudara, yang diawali oleh cerita tentang seorang perempuan menari di tengah tarian dikelilingi oleh orang-orang muda yang menginginkan tubuhnya, akhirnya ia meninggal di tari 9 lingkaran di Nunusaku. Lantas pecahlah persekutuan, mengingat tidak ada satu orang pun yang mau mengaku siapa sesungguhnya yang membunuh perempuan tersebut. Terjadi migrasi besarbesaran orang-orang Pata lima ke pesisir, sehingga membentuk klan baru, sehingga saat ini dapat kita temui wilayah dengan nama "negeri lima" di kepulauan Hitu dan orang-orang dengan marga siwalete, tomalima di Seram Timur, terdapat pula marga talalima, faolima, pesolima. Siwa lima mempunyai banyak versi. Namun dari beragam versi tersebut, pesan yang hendak disampaikan adalah dulu orang Nunusaku tinggal secara berdampingan.

Masyarakat Maluku Tengah mempercayai bahwa asal-usul kosmologi siwa lima berasal dari orang Alifuru di pulau Seram yang terbagi atas empat kelompok. Kelompok pertama adalah kelompok di Seram Timur. Kelompok ini tidak memiliki hubungan sedikitpun dengan tetangga-tetangga mereka. Kelompok kedua adalah kelompok Pata lima (kata pata dimaksudkan sebaga klen atau kelompok). Kelompok ketiga adalah kelompok Pata Siwa putih dan kelompok ke empat adalah kelompok Pata Siwa Hitam ${ }^{4}$ yang bertempat tinggal di Seram bagian Barat ${ }^{5}$.

Tulisan ini membahas tentang definisi siwa lima dan proses kemunculannya kembali karena dianggap mempunyai nilai pasifikasi serta rasa persatuan dalam menjaga perdamaian di Ambon pascakonflik. Menemukan redefinisi seperti apa konsep siwa lima yang sesuai. Pata Siwa dan Pata lima mempunyai arti orang yang ke 9 dan orang yang ke 5 (Ajawaila, 2009: 4).

Narasi diatas adalah salah satu dari puluhan, mungkin ratusan versi munculnya Pata Siwa dan pata lima. Namun demikian, terdapat kesepakatan umum bahwa tradisi Pata Siwa dan Pata lima di Seram ini dianggap sebagai sentrum dari tradisi tertua lainnya. Nenek moyang orang Seram dipercaya sebagai pusatnya kehidupan di bumi. Terdapat kepercayaan bahwa masyarakat kuno Seram mempunyai agama Nunusaku, sebagai agama tertua di

perubahan komposisi pranata sosial di Maluku Tengah. Beberapa kampung Islam Pata lima banyak yang masuk Kristen dan menjadi Pata Siwa. Sebagai misal kampung Prof. Mus Huliselan (mantan rektor Universitas Pattimura), Molot di Maluku Tengah, adalah Pata lima, namun jika dicermati semua adat yang diterapkan dan orientasi Baileo (rumah adatnya) adalah Pata Siwa. Hal ini karena Molot dahulu adalah kampung Islam yang masuk Kristen dan mengubah menjadi Pata Siwa. Rumphius melaporkan bahwa imamimam di kampung Molot pada 1600an mulai mengganti kepercayaan mereka. Demikian pula pada kampung Hulaliu di Pulau Pelaw, Maluku Tengah, yang masuk Kristen dan mengubah menjadi Pata Siwa ke Pata lima. Pada masa kolonial, terjadi pemindahan demografi secara besar-besaran. Salah satunya adalah pemindahan masyarakat dari Seram ke Pulau Ambon, demikian juga orang-orang dari Hitu dipindah ke Ruhu, sehingga segregasi Pata Siwa dan Pata lima menjadi demikian kocar-kacir. Kontestasi politik ini berbeda dengan model swa Lima di Aru dan di Maluku Tenggara, dimana unsur agama tidak begitu mempengaruhi orientasi siwa dan lima. Dengan demikian sulit sekali menelusuri secara tepat genealogi swa Lima dengan narasi penafsiran yang tunggal. Informasi dari Prof. Huliselan, 21 Oktober 2009.

${ }^{4}$ Perbedaan antara Pata Siwa Putih dan Pata Siwa Hitam secara jelas terletak pada penanda tubuh mereka. Anggota Pata Siwa Hitam membuat tato sebagai tanda keanggotaan, sekaligus juga sebagai anggota rahasia kakehan. Kakehan sendiri berarti tanda.

${ }^{5}$ Meskipun demikian beberapa penduduk di pantai di Seram bagian Barat termasuk dalam kelompok Pata Siwa putih seperti desa Lisabata, Noniali dan Sukaradja (Ajawaila, 2009: 7).

62 | Jurnal Lakon Vol. 1 No. 1 Mei 2012 
Maluku, ada bersamaan dengan munculnya pulau Ibu dari dasar laut. Berangkat dari sinilah muncul manusia pertama yang menyebar dan berkembang biak diseluruh pulau Seram dan Maluku. Persebaran menyebabkan semakin kompleksnya kebudayaan masyarakat yang semakin terklasifikasi dalam kluster-kluster berdasarkan marga, sistem mata pencaharian, organisasi sosial dan agama.

Tulisan ini membahas tentang definisi siwa lima dan proses kemunculannya kembali karena dianggap mempunyai nilai pasifikasi serta rasa persatuan dalam menjaga perdamaian di Ambon pascakonflik. Menemukan redefinisi seperti apa konsep siwa lima yang sesuai dengan masyarakat Ambon yang semakin beragam. Membangkitkan kembali sentimen adat dan tradisi lama bukan hanya untuk membantikan identitas yang resisten (Castells, 1997: 2), namun juga untuk memobilisasi massa berdasarkan kesamaan memori kolektif terhadap masa lalu, etnisitas, lokalitas, ketuhanan, kebangsaan, dan kesamaan bahasa (Hobsbawm, 1993: 2; Henley dan Davidson, 2007: 13). Revivalisme adat atau yanmenjadi sangat penting karena ia dianggap budaya yang paling "asli" dan "tunggal" sebelum datangnya klusterkluster agama-agama modern, kapitalisme modern dan solidaritas negara bangsa (Henley dan Davidson, 2007: 17, 31). Kearifan siwa lima diharapkan mampu menjadi penengah diantara munculnya polarisasi masyarakat Ambon dalam bentuk segregasi antar umat Islam dan Kristen, segmentasi antar entis serta polarisasi antara kaum pendatang dan masyarakat asli. Banyak analis melihat bahwa siwa lima semakin terlupakan seiring dengan modernisasi yang terjadi pada masyarakat Ambon. Kearifan lokal ini dianggap "ketinggalan jaman" dan tidak mempunyai ide yang sesuai dengan semangat modernisme. Karena itu, saya akan menelusuri trajektori orang Ambon yang mengalami modernisasi semenjak abad 18, sehingga akan ditemukan logika mengapa kemudian siwa lima menjadi kearifan lokal yang terlupakan.

\section{Munculnya Modernitas Orang Ambon ${ }^{6}$, Polarisasi Islam-Kristen dan Tercerabutnya Tradisi}

Modernitas orang Ambon mulai terbangun semenjak kekuatan kolonial membangun pulau ini berdasarkan rasionalitas klas penguasa, dengan menciptakan kluster-kluster berdasarkan ras, etnisitas dan agama. Layaknya wilayah lainnya di nusantara, dibawah pemerintahan resmi Belanda, penduduk di Pulau Ambon secara vertikal dibagi ke dalam tiga kelompok, yang mengacu kepada ras, yakni masyarakat Eropa (Vrijbugerij), orang-orang Cina dan kaum sipil urban (Burgerij). Kategori pertama adalah orang Portugis yang masih menetap meski Belanda telah menguasai seluruh pulau Ambon. Mereka juga disebut sebagai Casado. Sedangkan masyarakat ketiga disebut pula sebagai kaum Mardijker. Hingga detik ini keturunan mereka masih menempati sebuah wilayah yang disebut Mardika. Kaum pribumi mempunyai posisi istimewa meskipun otoritas menciptakan keputusan sangat terbatas.

\footnotetext{
${ }^{6}$ Kata Ambon disini sebenarnya agak rancu, mengingat ia tidak hanya mengacu pada kota Ambon, namun juga mengacu pada Pulau Ambon dan sekitarnya (Pulau Buru, Pulau Banda), serta orang-orang di kepulauan Maluku Tenggara yang mendefinisikan sebagai "orang Ambon" tatkala mereka berada di luar Maluku. Kata ini sengaja saya pilih karena mempunyai makna yang fleksibel secara identitas dan geografis, dibanding saya harus menggunakan kata "Maluku Tengah", "Seram" atau "Maluku Tenggara"
} 
Diciptakannya pola kepemimpinan dalam masing-masing kelompok non-Eropa merupakan strategi adaptasi pemerintah untuk menggabungkan sistem politik koloni dengan bentuk pemerintahan adat atau masing-masing etnis. Layaknya kota kolonial lainnya, internal Ambon disegregasi dan diklasifikasi berdasarkan kekuatan ekonomi dan politik masyarakat dan bukan berdasarkan rasionalitas persekutuan siwa lima.

Pulau Ambon mengalami modernitas ketika terjadi peralihan dari kota kerajaan ke kota kolonial. Munculnya kota kolonial, otomatis merubah wajah sistem sosial masyarakat nya, dari yang berpegangan pada pekerjaan agraris ke arah perdagangan (Bartels, 287: 1979). Pada pertengahan abad 17, Ambon juga disebut sebagai wilayahnya orang migran, karena penduduk asli Ambon hanyalah sebesar 5\%, sedangkan sisanya sebesar 95\% adalah pendatang. Dengan kata lain, pada tahun 1694 penduduk Ambon hanya sebesar 274 jiwa dari 4.487 jiwa dari keseluruhan warga di kepulauan Ambon. Pertumbuhan kaum urban muncul pula secara pesat. Ambon menunjukkan wajah kosmopolitannya. Munculnya kaum migran ini otomatis mengaburkan dualisme konsep siwa lima yang dipandang hanya bermuatan oposisi biner, gunung-laut; hitam-putih. Pesatnya pendatang tentu semakin mengabaikan kosmologi ini.

Hingga di Abad 19, agama Kristen berkembang pesat. Gereja-gereja terbangun dan tumbuh dengan terorganisir secara kuat (Cooley, 143-4: 1961; Abdul Kadir, 35-51: 2009). Masuknya urban Ambon ke agama Kristen, merupakan peralihan dari Katolik yang dianggap kejam dan tukang menjarah. Juga mereka tidak memilih Islam dikarenakan identik dengan tukang penginvasi dari utara yakni kerajaan Ternate dan Tidore. Meskipun pada akhirnya masih meninggalkan pertanyaan bahwa aliansi ke dalam agama Kristen cenderung bersifat politis dibanding refleksi relijiius yang mendalam. Konstruksi kekuasaan mengacu kepada kegiatan-kegiatan agama Kristen seperti komuni suci yang mentransfer kekuasaan dan kekuatan Belanda terhadap penganut Kristen di Ambon (Bartels, 1979: 287; 2003: 12). Umat yang beralih memeluk agama Kristen, tidak hanya akan mendapatkan tingkat previlese yang lebih dibanding orang Cina maupun migran Jawa, Makassar dan Buton, melainkan juga mereka akan aman dari serangan kelompok etnis lainnya yang tidak memeluk agama Kristen. Menjadi Kristen selama masa koloni adalah menjadi orang modern, berpendidikan, berperadaban dan akan mempunyai status lebih berkuasa di tingkat struktural pemerintahan lokal.

Transfer kekuasaan "White Power" koloni terasa tatkala Belanda memperkenalkan sistem pembapitsan dan sakramen terhadap tubuh orang-orang Ambon. Jika sebelumnya pada masa head hunting kekuatan dan kesucian tubuh berparamater pada sejauh mana tenggorokan pernah dibasahi oleh darah lawan, maka makna tubuh suci modern dan kekuatannya beralih ke sepotong roti suci dan secawan anggur yang dipercaya sebagai manifestasi Tubuh dan darah Kristus (Bartels, 287: 1979). Selanjutnya Knaap

\footnotetext{
${ }^{7}$ Beberapa sumber sejarah menyebutkan bahwa bahwa Pata Siwa dan pata lima bukanlah kearifan lokal yang berasal dari Seram, melainkan berasal dari Kesultanan Tidore dan Ternate. Pata Siwa mempunyai pertaliannya dengan Ternate dan Pata lima dengan Tidore. Alasan munculnya pembagian Pata Siwa dan pata lima adalah adalah untuk memecah belah orang Seram agar lebih mudah ditaklukan. Berbagai catatan sejarah memperlihatkan bahwa orang Ternate dan Tidore terus bersaing paling tidak sejak tahun 1450 .
}

64 | Jurnal Lakon Vol. 1 No. 1 Mei 2012 
mengestimasikan bahwa sepeninggal Portugis pada tahun 1605 ada sekitar 16 ribu orang Ambon yang dibaptis di Lei Timor dan di kepulauan Lease ${ }^{8}$ (Knaap, 1987: 83 via Chauvel 1990: 18). Ritual baptisme melalui pemandian suci merupakan purifikasi tubuh yang sekaligus membatasi manusia lama menjadi manusia baru. Menjadi siap modern adalah beragama Kristen dan terpisah dengan masyarakat pagan sebelumnya. Terjadi ruang pemisahan tubuh antara kelompok bersih dan suci (Kristen, Ambon dan orang kota) dan kelompok kotor (Islam, pesisir, masyarakat pedalaman seperti di Alifuru). Pengalaman relijius tidak pernah mandi suci memisahkan urban Kristen dengan mereka yang belum pernah melakukannya, dan distereotipekan sebagai manusia yang tidak tercuci (unwashed people) yang tidak bersih. Hingga tahun 1935, para pemimpin gereja reformis yang dikomandoi oleh GPM (Gereja Protestan Maluku) melakukan serangkaian tindakan purifikasi secara ofensif terhadap para penganut adat hingga ke desa-desa. Di titik inilah kemudian kolonialisasi dan agama menjadi aktor penentu dalam memodernkan pilihanpilihan untuk menentukan kemana hendak diarahkan tubuh ketika menghadapi perubahan. Modernisasi agama mengubah konsep kosmologi siwa lima yang pada awalnya adalah persekutuan adat an sich, mengerucut pada polarisasi antara siwa yang identik dengan Kristen dan lima yang identik dengan Islam. Belanda mempunyai logika modernisme dengan menciptakan elit-elit lokal baru dibanding harus merawat adat istiadat masyarakat jajahan.

Tepatnya tahun 1882, disebutkan bahwa dari jumlah jiwa di kepulauan Ambon (Haruku, Saparua, dan Nusalaut) jumlah kaum muslim mencapai 28,3\% atau berjumlah 16.693 manusia dari total 58.893 jiwa. (Hulsboch 129: 2004). Di marjinalkannya komunitas Islam sepanjang masa koloni, membuat agama ini lebih statis dalam mempertahankan nilai tradisional Ambon. Belanda tidak memperkenalkan kepada komunitas Islam, sistim pendidikan yang berlanjut pada sistim pekerjaan modern. Sehingga kaum muslim nyaris tidak mengenal alokasi dana untuk belanja pakaian dan juga tidak tertarik dengan gaya hidup modern (Chauvel 35-8: 1990; Hulsboch, 106: 2004).

Sedangkan modernitas orang-orang Islam di kota ini masuk secara belakangan dibanding orangg-orang Kristen. Pada tahun 1933 gerakan-gerakan purifikasi yang menyerang takhyul dalam adat mulai marak, salah satunya adalah dengan didirikannya sebuah masjid besar di tengah kota yang kini lebih dikenal dengan Masji Al-Fatah. Konflik antara penerimaan Islam progresif dengan tetap mempertahankan nilai-nilai tradisional cenderung terjadi dengan hebat dan berdarah-darah di wilayah luar Ambon, seperti pada orang-orang Haruku dan Pelauw, sebuah wilayah yang berada di ujung timur Pulau Ambon. Gerakan purifikasi yang digiring oleh Islam juga dilakukan terhadap masyarakat urban Ambon. Masuknya dua agama besar di Ambon (Kristen dan Islam) membuat warga urban mengalami peralihan kebimbangan antara tetap mempertahankan tradisi leluhur atau mulai memasuki agama modern. Gerakan purifikasi, baik pada masyarakat Islam maupun Kristen mau tak mau mengancam keberadaan kosmologi siwa lima yang dianggapnya penuh takhyul adat, bid'ah, kolot dan tak suci. Tak lama kemudian, modernitas mulai mengikis

\footnotetext{
${ }^{8}$ Orang-orang di Kepulauan Lease meliputi orang Ambon, Saparua Nusalaut, Haruku, dan Molana
} 
keperacayaan terhadap satu-satunya tradisi agama Nunusaku dan tunggalnya adat serta nenek moyang orang Ambon.

Periode pascakolonial di tahun 1950an, masyarakat Ambon telah mengalami semacam "kebingungan" identitas, sebagaimana yang digambarkan oleh disertasi Cooley di Yale University mencatat bahwa:

This period has been a time in which the youth have come increasingly to the fore. Educational opportunities have grown tremendously. Moluccan Christians have been confronted by more self-conscious and aggressive Moluccan Muslims. Indirect government through the Village Councils by a colonial government has been replaced by direct government by Indonesians, themselves determined to build a new nation. This set of circumstance here referred to broadly as "rapid social change"... The adat system has further broken up. Only particular parts of it remain. More important still, respect for and reliance on adat has suffered grievously, particularly amongst the younger generation. (Cooley,155:1961).

Pasca revolusi, secara garis besar orang Ambon terbagi dalam dua karakteristik, yakni kaum modernis dan tradisionalis. Golongan pertama adalah mereka yang tinggal di kota, berpendidikan, dan mempunyai orientasi nasionalisme serta mempunyai ikatan terhadap imaji negara bangsa secara kental. Sedangkan golongan kedua adalah mereka yang masih menempati desa dan terikat kuat dengan nilai-nilai adat seperti misal tetap berpegangan pada kearifan siwa lima. Meskipun demikian, kesamaan dari keduanya adalah tetap bergelayut dengan dunia tradisional bagi mereka yang modern, dan berhasrat mengetahui peradaban di luar yang modern bagi mereka yang tradisionalis. Pada titik inilah kemudian orang-orang Ambon Modern sebenarnya mulai meninggalkan tradisi siwa lima dengan berpegangan pada model "kearifan filosofis" baru yang ditawarkan oleh agama dan Negara bangsa baru, seperti Pancasila.

Orang Kristen adalah komunitas yang paling merasa terganggu dengan datangnya ide nasionalisme tentang Keindonesiaan. Baginya, dominasi kulit putih adalah lebih baik dibanding dominasi Indonesia, sebuah negara yang baru dikenal. Dekolonisasi menyebabkan perubahan komposisi pemerintahan. Tidak ada lagi keistimewaan status yang diasosiasikan dengan Belanda. Pada saat yang sama muncul gelombang migran yang disebut sebagi "Islam Pendatang" atau "orang dagang". Rata-rata dari mereka menempati lahan kosong yang tersedia di sepanjang bantaran sungai dan pesisir pantai kota (Mearns, 25: 1999; Benda Beckmann, 2007: 15-25). Jumlah orang muslim kemudian semakin membludak hingga mencapai puncak di pertangahan tahun 1990-an. Transformasi mulai berjalan karena yang berhak mendapatkan pendidikan, previlese, dan gaya bukan hanya anak muda Kristen, namun juga anak-anak muda Islam yang tinggal di Ambon.

Kaum migran ini rata-rata berasal dari Buton, Makassar, Bugis, Jawa dan sisa-sisa dari kepulauan Maluku yang terpencar. Hingga menjelang tahun 1995 gelombang migran muslim membengkak nyaris menyamai jumlah kaum urban Kristen. Ketika itu populasi kota ini mencapai 311,000, 52.9 jiwa. Jumlah Kristen sebanyak 41,7 persen, katholik 5,2 persen . Layaknya komposisi sebelumnya, komunitas Islam menempati wilayah pesisir pantai, 
dengan membentuk komunitas-komunitas pedagang di pasar. Para migran muslim rata-rata bekerja sebagai pedagang, sedangkan kebanyakan Kristen mewarisi tradisi yang telah terbangun selama masa kolonial, yakni bekerja dijasa birokrasi. Meski demikian hingga tahun 1999, setidaknya terdapat 74 persen muslim yang menempati elit pemerintahan (Basorie, 62-3: 2005; ICG Asia Report, 2: 2000). Ketakutan terhadap sebentuk hegemoni yang akan lahir dari satu sisi golongan misalnya, menjadi klausul yang cukup menjadi alasan untuk kembali memunculkan ide tentang siwa lima. Namun, semangat ini menjadi tantangan pesatnya perkembangan Islam garis keras pasca konflik memandang negatif kearifan lokal asli masyarakat Ambon ini, karena dianggap tidak sesuai dengan nilai-nilai Islam yang murni selayaknya di Timur Tengah.

\section{Siwa lima Sebagai Kearifan Lokal Orang Ambon}

Siwa lima adalah persekutuan adat dan persekutuan kelompok. Secara harfiah Siwa lima terbentuk oleh dua kata, yaitu Siwa dan Lima. Siwa berarti sembilan (9), lima berarti (5). Kedua terminologi ini menunjukkan pemisahan atau pembagian masyarakat atas dua kelompok sosial yang berbeda, yakni kelompok sembilan dan kelompok lima. Indikator dari beberapa aspek pembeda budaya dalam siwa dan lima dapat dilihat melalui arsitektur, upacara daur hidup, penanda pada tubuh dan pakaian. Ikatan kesatuan dan pertalian antara kedua kelompok ini juga berbeda dalam hal bahasa, sistem kepercayaan, tentang proses terjadinya pemisahan yang masih menimbulkan banyak perdebatan, penafsiran dan klaim. Namun demikian, siwa dan lima tidak berbeda dalam melihat mitologi asal-usul mereka, yakni sama-sama berasal dari Seram.

Dalam kosmologi orang Ambon, kedua angka 9 dan 5 ini penting dan memiliki makna mendalam. Angka lima memperlihatkan sebuah gagasan tunggal yang bermakna totalitas dan sembilan menunjukkan sebuah gagasan jamak atau ganda yang juga bermakna totalitas. Sebagai misal adalah seorang manusia memiliki dua tangan, dua kaki dan satu kepala, total berjumlah lima, namun memiliki gagasan tunggal sebagai tubuh manusia. Di lain pihak, dua orang (laki-laki dan perempuan) yang memiliki empat tangan dan empat kaki serta memiliki satu kepala memperlihatkan sebuah gagasan tunggal dalam perspektif jamak yaitu memperlihatkan perbedaan dalam hal gerakan tangan dan kaki, namun memiliki satu kepala sebagai representasi kebersamaan, kesepakatan, seia-sekata dalam kehidupan harmoni dari dua orang yang menjadi satu. Dengan demikian, total yang dapat dihitung dari jumlah keseluruhan diatas adalah $2+2+1=5=1$ dan $4+4+1=9=1$ Sehingga dari esensi dari kejamakan lima dan sembilan diatas adalah satu (satu) (Ajawaila, 2009: 3). Berangkat dari analogi tubuh ini orang Ambon percaya bahwa meski tubuh (tangan dan kaki) mereka berbeda (baca: Islam-Kristen) namun mempunyai kepala yang sama atau tunggal (baca: nenek moyang agama Nunusaku, di Seram).

Pertanyaannya kemudian adalah mengapa angka 9 dan 5 yang dipilih, mengapa bukan satu, atau tiga, atau tujuh, atau angka lainnya? Logika yang digunakan adalah menggunakan lingkungan yang paling dekat dan menjadi pelaku serta bagian dalam pengalaman kehidupan sehari-hari, tidak lain dan tidak bukan adalah tubuh manusia. Logika yang dibangun kemudian seperti yang telah saya gambarkan diatas, dimana jumlah 
total lima dapat berarti kepala, tangan dan kaki atau jumlah jari pada satu lengan. Sedangkan logika total dari angka sembilan bisa kepala, dua pasang tangan dan dua pasang kaki atau jari dari kedua lengan dimana ibu jari berhimpitan menjadi satu. Selain tubuh, lingkungan alam terdekat menjadi bagian dari ajaran filosofisnya, seperti gunung, laut, dan biota di dalamnya (Huliselan, 2009: 2-5).

Dalam tataran praktis dan ritual, angka 9 dan 5 menjadi penting, dalam upacara adat, hal yang mengacu pada 9 mempunyai peranan penting, misalnya pada upacara perkawinan dimana pengantin harus berjalan mengelilingi rumah 9 kali atau mengucapkan mantera 9 kali. Demikian pula bagi mereka yang melanggar adat diharuskan membayar harta lengkap sebagai denda perang dalam bentuk 9 buah bendera, 9 buah mangkuk (kom ) dan pinggan pinggan besar, 90 buah piring-piring tua, 500 piring kecil dan 5 buah gong. Sedangkan bagi masyarakat pata lima, bagi mereka yang melanggar adat dikenakan denda masing-masing 5 buah kom, 50 buah piring tua, 500 piring kecil dan 5 buah gong (Ajawaila, 2009: 9-10). Angka-angka ini dijaga dengan penuh kepatuhan mengingat dianggap mengadung nilainilai yang sakral. Tari tradisional Gaba-Gaba juga merupakan salah satu tarian yang mengesankan unsur Siwa lima. Tari ini dilakukan oleh satu penari dengan empat penari memegan galah dan sembilan penari Cakalele. Iringannya adalah Tifa (Instrumental tradisional). Tari ini menggambarkan sikap pertahanan dari serangan musuh.

Di Jazirah Hitu terdapat pula siwa dan lima. Secara historis, dua persekutuan adat ini menentang pendudukan Belanda. Namun demikian, pada saat ini semagant siwa lima sudah tidak digunakan lagi dalam upacara-upacara adat (Rumphius, 1983). Bahkan sebuah catatan sejarah Rijali melaporkan bahwa siwa-lima ini menjadi ritus peribadatan paling kuno orangorang Hitu (Sifar ar Rijal, Hikayat Tanah Hitu). Sedangkan disebut dengan negeri lima di Hitu, sebenarnya mengacu pada batas antara siwa dan lima. Namun demikian, masyarakat Hitu sekarang lebih mengenal istilah negeri lima, dibanding siwa lima. Modernitas yang diwakili oleh datangnya agama Islam menyebabkan masyarakat menggerus tradisi lama siwa lima ini dan lebih menempatkan siwa identik dengan agama Kristen dan lima identik dengan agama Islam. Kedatangan Islam dan Kristen yang kemudian menyebabkan orangorang Hitu lebih memilih untuk meneruskan tradisi ulilima saja dibanding ulisiwa.

Sedangkan dalam bentuk material modern, semangat siwa lima tampak pada bentuk rumah Baileo yang terletak di Taman Mini Indonesia Indah (TMII) ${ }^{9}$ dengan mengusung semangat siwa lima yang melambangkan representasi persatuan atau persekutuan antara dua klen besar di Maluku yaitu Pata Siwa dan Pata lima (di Seram). Dalam rumah adat Baileo ${ }^{10}$ terdapat tiang bailen di depan dan belakang berjumlah 9 sedangkan sisi kiri dan dan kanan berjumlah 5. Pemerintah Orde Baru menganggap otentik bangunan tradisional ini karena mengusung ide persatuan di seluruh daerah Maluku. Dengan tiang-tiangnya yang berjumlah

\footnotetext{
${ }^{9}$ Taman mini Indonesia ini mengusung otentisitas dan simplifikasi dari berbagai budaya pilihan seluruh Nusantara yang dianggap paling terkemuka dan mewakili masing-masing wilayah etnis di Indonesia. Pada masa Orde Baru, pemerintah melihat bahwa swa Lima adalah representasi yang cukup bagus dalam mewakili budaya Indonesia.

${ }^{10}$ Kata Baileo berarti "balai bersama" yakni sebuah rumah yang sekaligus berfungsi sebagai ruang yang mempertemukan organisasi masyarakat dan masyarakat adat lokal untuk membahas berbagai permasalahan yang mereka hadapi dan mengupayakan berbagai pemecahannya.

68 | Jurnal Lakon Vol. 1 No. 1 Mei 2012
} 
9 dan 5 diharapkan rumah tradisional ini mampu menjadi pelindung yang kokoh dan berfungsi sebagai tempat bermusyawarah dan pertemuan rakyat dengan dewan rakyat seperti saniri negeri, dewan adat dan para tetua adat. Sedangkan di Ambon sendiri, untuk menegaskan kosmologi lokal nan arif ini, dibangun museum, warta lokal, perkantoran, hingga simbol pemerintahan provinsi yang meminjam nama "siwa lima".

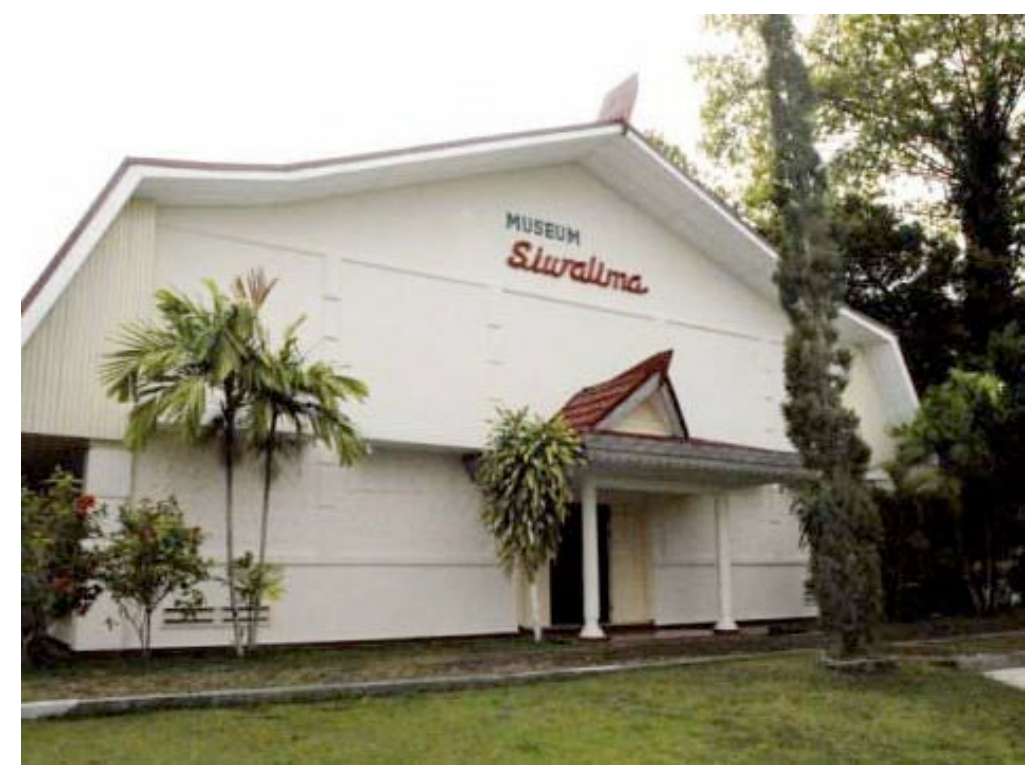

Gambar 1. Museum lokal Siwa lima, berdiri di tahun 1973 di Air Salobar, menegaskan identitas kearifan lokal masyarakat Maluku

Sedangkan orientasi siwa-lima dalam rumah adat Baileo juga ditentukan pada posisi batu pamali (batu keramat) yang diletakkan. Jika posisi batu pamali terletak antara baileo dengan pantai, maka itu pata lima, sedangkan jika batu pamali terletak diantara baileo dengan gunung, maka masyarakatnya berpegangan pada Pata Siwa. Dengan demikian kosmologi orang Ambon adalah gunung (identik dengan Pata Siwa dan Kristen) dan pantai (identik dengan pata lima dan Islam), ini berbeda dengan kosmologi masyarakat Jawa yang mengacu pada arah utara dan selatan atau kosmologi mayarakat Bali yang mengacu pada kaja-kelod (gunung-laut) sekaligus depan-belakang. Meski acuan demikian, acuan gununglaut ini tidak bisa benar-benar menjadi jaminan mutlak dalam melihat kosmologi orang Ambon, mengingat telah banyak perubahan dalam kosmologi siwa lima itu sendiri. Mengingat pula, Ambon dan kepulauan Lease adalah wilayah yang paling banyak mendapatkan campur tangan koloni Belanda dalam mengubah kosmologi siwa lima tersebut.

Siwa lima merupakan konsep masyarakat Maluku yang berfalsafah dalah menghadapi perbedaan dan keragaman kebudayaan masyarakatnya. Konsep ini banyak dijumpai tidak hanya di Seram dengan Pata Siwa dan Pata lima nya dan Uli Siwa serta Uli Lima, namun juga di wilayah Maluku Tenggara dengan konsepnya Lorsiw- Lorlim bagi masyarakat Kei dan Ursiw-Urlima ${ }^{11}$ bagi masyarakat Aru. Siwa lima di daerah Maluku

\footnotetext{
${ }^{11}$ Ursiw mengacu pada angka sembilan, dengan unsur kerbau, hiu martil, daratan langit dan gunung. Sedangkan urlima mengacu pada paus, lautan, bumi dan pantai. Sedangkan shared culture dari dua hal yang berbeda ini adalah larwul ngabal, yakni hukum adat Kei yang didalamnya terdapat pasal antara lain: Uud entauk na atvunad (Kepala kita berada di atas leher); Lelad ain fo mahiling (Leher kita dihormati); Uil nit
} 
Tenggara mencakup Maluku Tenggara Barat, berbagai Pulau di Aru, dan wilayah Maluku Barat Daya. Siwa lima di Maluku Tenggara ini mempunyai semangat yang sama dengan di Maluku Tengah dan Ambon, yakni dua orang bersaudara layaknya kakak adik yang mempunyai karakter berbeda, namun tetap satu darah dan satu semangat (Huliselan, 2009: 2).

Secara praktis falsafah ini kemudian menjadi semacam persekutuan adat dan politik. Pandangan siwa lima berangkat dari pandangan bahwa dalam kebudayaan yang bersifat monodualistik dan penuh dengan perbedaan, keadilan, kerjasama, dan pemerataan harus diterapkan sesuai dengan adat, demi mencapai keharmonisan. Jika menegasikan satu identitas, maka eksistensi kebudayaan atau adat yang lain sesungguhnya tidak ada. Karena itu masing-masing individu dalam adat, musti mengenal dan saling bekerja sama satu dengan yang lainnya. Di tingkatan struktural, siwa lima ini menghasilkan sebuah ikatan emosional antar warga yang disebut dengan pela-gandong ${ }^{12}$. Pranata sosial pela-gandong ini merupakan puncak produk pemikiran dari Pata Siwa-pata lima. Berbeda dengan siwa lima, sebagian besar dari sistem pela-gandong dibuat ketika pendudukan Belanda, khususnya ketika Seram dan Ambon mengalami kekacauan luar biasa akibat sistem politik perdagangan monopoli Hongi-Tochten (ekspedisi Kapal Hongi) terhadap harga cengkeh ${ }^{13}$.

Berangkat dari kearifan dan kejeniusan masyarakat lokal inilah, kemudian siwa lima dijadikan sebagai modal sosial dan juga modal politik bagi masyarakat dan pemerintahan dalam membangun kembali pola-pola kehidupan masyararakat yang baru saja mengalami konflik berkepanjangan. Redifinisi terhadap siwa lima paca kerusuhan Ambon bertujuan untuk meggerakkan kebersamaan masyarakat, membangun rasa saling percaya serta mencapai keuntungan secara bersama. Semangat siwalima digunakan dan diredefinisikan

enwil rumud (Kulit bumi menutupi badan kita); Lar nakmot na rumud (Darah terkurung dalam badan kita); Rek fo kilmutan (Perkawinan harus terjadi di tempat yang suci dan keramat); Morjain fo mahiling (Tempat wanita dihormati); Hira I ni fo I ni, it do fo it did (Milik seseorang adalah miliknya, milik kami adalah punya kami). Periksa selanjutnya: J.P Rahail, Larwul ngabal hukum adat Kei : bertahan menghadapi arus perubahan, Yayasan Sejati, Jakarta 1993; P.M Laksono, Ken Sa Faak: Benih-benih perdamaian dari Kepulauan Kei, Insist Press, 2004.

${ }^{12}$ Pela-Gandong adalah sistem hubungan sosial yang mengikat dengan masyarakat di luar kampungnya sendiri. Pela merupakan suatu relasi perjanjian dengan satu atau lebih negeri lain yang sering berada di pulau lain dan kadang juga menganut agama lain. Satu kampung terkadang memiliki dua hingga tiga pela. Sehingga sistem pela-gandong ini menciptakan masyarakat jaringan di Maluku Tengah. Sedangkan jenis pela terbagi dalam tiga hal, yaknji (1) pela karas; (2) pela gandong atau bungso;dan (3) pela tempat sirih. Pela keras muncul karena terjadi peperangan hingga menumpahkan darah. Pela gandong dimunculkan berdasarkan ikatan turunan, ikatan mata rumah (kekerabatan) dalam satu kampung dengan lebih dari satu mata rumah. Sehingga menimbulkan kepercayaan bahwa mata rumah membentuk jaringan sosial yang menganggap dirinya dari satu nenek moyang. Sedangkan pela tempat sirih diadakan ketika usai terjadi konflik kecil dan bertujuan untuk memulihkan keamanan serta memperlancar hubungan perdagangan. Sistem hubungan sosial ini telah dibahas dengan serius oleh Dieter Bartels dalam disertasinya "Guarding the Invisible Mountain: Intervillage Alliances, Religious Syncretism and Ethnic Identity Among Ambonese Christians and Moslems in the Moluccas (1997)“, dan beberapa karya tulisnya seperti "Alliances Without Marriage: Exogamy, Economic Exchange, and Symbolic Unity Among Ambonese Christian and Moslems" (1980) dan "Hubungan Pela di Maluku Tengah dan di Netherland" (1977).

${ }^{13}$ Periksa sejarah Hongi Tochten dalam monopoli perdagangan cengkeh ini di Charles Ralph Boxer, The Ducth Seaborne Empire 1600-1800, Hutchinson\&Co, 1977: 99-100; R.A. Donkin, Between East and West: The Moluccas and the Traffic in Spices up to the Arrival of Europeans. Philadelphia: American Philosophical Society, 2003.

70 | Jurnal Lakon Vol. 1 No. 1 Mei 2012 
kembali karena dianggap mempunyai muatan yang bersifat fungsionalis dalam memenuhi kebutuhan suprastruktur masyarakatnya. Meningkatnya konflik, menyebabkan orang-orang Pata Siwa merefleksikan posisi mereka untuk berdamai dengan pata lima dan kemudian menciptakan pranata sosial pela-gandong dengan mengacu pada satu nenek moyang sebagai asal-usul mereka yakni agama Nunusaku di Pulau Seram. Di sisi lain, pemerintah Maluku juga memperkenalkan pranata sosial tradisional lainnya seperti maren, masohi, swen, sasi, hawear yang meskipun tidak "setenar" konsep pela-gandong namun semuannya merupakan modal kearifan masyarakat yang tak kalah signifikan untuk menjadi modal sosial dalam menjalin keharmonisan antar manusia dan lingkungan. Munculnya semua pranata sosial ini lebih merupakan strategi untuk menjaga keharmonisan setelah menghadapi konflik yang berkepanjangan, sebagai misal, hubungan antar pela daerah $\mathrm{A}$ dengan daerah $\mathrm{B}$, berasal dari adanya memori terhadap bantuan perang yang pernah diberikan daerah $\mathrm{A}$ terhadap $\mathrm{B}$.

Pada perkembangan selanjutnya, dibalik falsafah siwa lima, sesungguhnya terdapat dua atau bahkan lebih kelompok yang hidup dalam keadaan bertentangan satu sama lainnya, sebagai misal antara masyarakat Islam-Kristen, dua agama ini mempunyai pandangan mikrokosmos berbeda, namun disatukan dalam sebuah nilai-nilai bersama (common values) atau kebudayaan yang terbagikan (shared culture) sebagai mediasi dari dua pertentangan tersebut. Mediasi ini merupakan proses keseimbangan dalam mencari keharmonisan hidup, stabilitas dan inklusivitas terhadap orang lain (the others). Karena itu siwa lima mempunyai prinsip monodualistik, yakni terdapat makna kesatuan didalam dua perbedaan yang ada, antara Pata Siwa dan pata lima. Meskipun sembilan, totalitasnya satu, meskipun lima totalitasnya pun tetap satu. Jadi tidak bisa dianggap 9 dengan totalitas sembilan, dan 5 dengan totalitas lima.

Berangkat dari kearifan dan kejeniusan masyarakat lokal inilah, kemudian Siwa lima dijadikan sebagai modal sosial dan juga modal politik bagi masyarakat dan pemerintahan dalam membangun kembali pola-pola kehidupan masyararakat yang baru saja mengalami konflik berkepanjangan. Redifinisi terhadap siwa lima paca kerusuhan Ambon bertujuan untuk meggerakkan kebersamaan masyarakat, membangun rasa saling percaya serta mencapai keuntungan secara bersama. Semangat siwalima digunakan dan diredefinisikan kembali karena dianggap mempunyai muatan yang bersifat fungsionalis dalam memenuhi kebutuhan suprastruktur masyarakatnya.

\section{Membangkitkan Ulang dan Mendefinisikan Kembali Siwa lima}

Siwa lima mengalami perubahan penafsiran sejak paska konflik. Sebelum masuknya modernisasi dan polarisasi antara agama Islam dan Kristen, masyarakat pendatang dan masyarakat Asli, pandangan kosmologis siwa lima hanya dilihat pada tataran keharusan memenuhi angka-angka sakral 5 dan 9 di wilayah ritual dan transisi, seperti pernikahan, kematian dan upacara pembayaran denda. Paska konflik agama, satu dekade lalu, siwa lima mulai mengalami redifinisi perluasan makna dan tujuan, yakni mempertahankan harmoni antar masyarakat-masyarakat yang baru saja melakukan konflik, menghargai para pendatang, dan bekerjasama dalam ruang-ruang multikultural, yang sebelumnya belum pernah dibangun 
dalam konsep siwa lima "lama". Bahkan konsep harmonisasi siwa lima juga dianggap sesuai jika dihubungkan dengan semangat UUD 1945, sebuah ide pascakolonial yang mengaspirasikan semua kepentingan bersama dari latar belakang masyarakat yang berbeda. Layaknya penemuan terhadap pancasila sebagai lambang negara, Ambon pascakolonial menemukan lambang siwa lima dengan memunculkan unsur-unsur yang identik dengan nilai kearifan lokal ini, yakni perisai, daun sagu, daun kelapa, mutiara, pala, cengkeh, tombak, gunung, laut dan perahu. Lambang-lambang yang disatukan dalam totalitas perisai ini identik dengan lingkungan kehidupan masyarakat dan dianggap punya peran penting bagi kehidupan masyarakat Maluku.

Beberapa ide menarik juga hendak memasukkan kearifan lokal ini dalam kurikulum pendidikan dasar bermuatan lokal dengan tujuan mengungkap potensi siwa lima sedini mungkin pada anak didik. Kearifan lokal ini juga hendak diintegrasikan dengan pendidikan agama, dengan mencari persamaan pada semangat etika kerjasama dan kebaikannya ${ }^{14}$. Membangkitkan muatan lokal kearifan siwa lima menjadi sangat penting, mengingat selama ini beberapa pakar pendidikan di Maluku selalu mengeluh bahwa sejarah nasional untuk tingkat dasar selalu menyampikan narasi tentang sejarah raja-raja Jawa, Ken Arok, kerajaan Majapahit hingga raja-raja Mataram, tapi bukan kearifan lokal dan sejarah lokal masyarakat Maluku itu sendiri. Redefinisi terhadap siwa lima menimbulkan dua pandangan dalam hal pencetusnya, yakni pelaku budaya pada masa prakolonial dan kedua adalah pemerintah daerah yang kini gencar-gencarnya membangkitkan kembali tradisi tersebut. Berangkat dari semangat siwa lima tradisional/lama, siwa lima "model baru" yang dicanangkan oleh pemerintah dianggap lebih multikultural mengingat orang Ambon pascakolonial kini berhadapan meningkatnya pesatnya para migran, kepentingan negara dan segregasi agama yang semakin menajam.

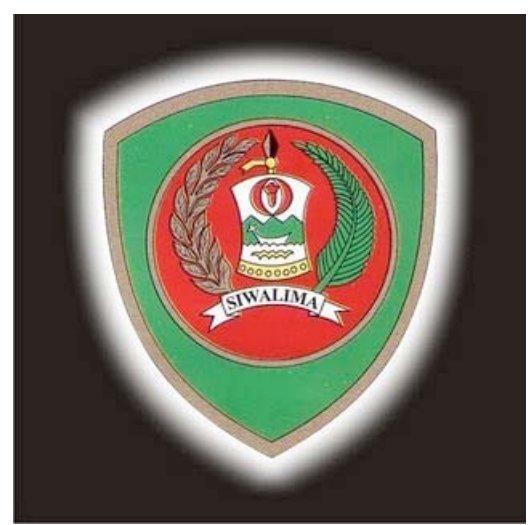

Gambar 2. Lambang pemerintahan Maluku yang mengambil semangat dari siwa lima

Meski demikian, redefinisi konsep siwa lima ini seringkali dicurigai sebagai "proyek" semata dari pemerintah, dibanding muncul dari inspirasi rakyat di tingkat bawah."Kearifan lokal model baru" ini dianggap tidak pro rakyat, dan cenderung hanya menjadi propaganda pemerintah provinsi semata. Semangat siwa lima baru juga dianggap tidak begitu melibatkan

\footnotetext{
${ }^{14}$ Ide ini mulai dicanangkan oleh salah satu SMA Muhammadiyah Ambon yang juga mempunyai 7 guru kristen didalamnya.
}

72 | Jurnal Lakon Vol. 1 No. 1 Mei 2012 
tetua adat seperti upulatu, baparaja dan tetua lainnya yang tinggal di baileo di daerah-daerah. Contoh paling terbaru adalah sebuah penghargaan yang diberikan oleh presiden SBY, dengan gelar "Upu Latu Rat Maran Siwa lima" (Raja Besar Maluku) oleh Majelis Latupati Maluku. Masyarakat menganggap bahwa penghargaan sakral ini hanyalah sebuah agenda "cari muka" dari para petinggi birokrasi lokal terhadap presiden, mengingat selama ini presiden SBY tidak dianggap benar-benar ikut andil dalam menyelesaikan konflik di Ambon, melainkan atas inisiatif masyarakat sendirilah konflik tersebut selesai. Masyarakat di tingkat bawah juga menganggap bahwa majelis adat latupati Maluku yang dipimpin oleh A Malawat (Bapa Raja Negeri Mamala) telah dibujuk oleh para petinggi di kantor gubernur Maluku untuk menguatkan pemberian gelar tersebut kepada pemimpin tertinggi di Indonesia ini.

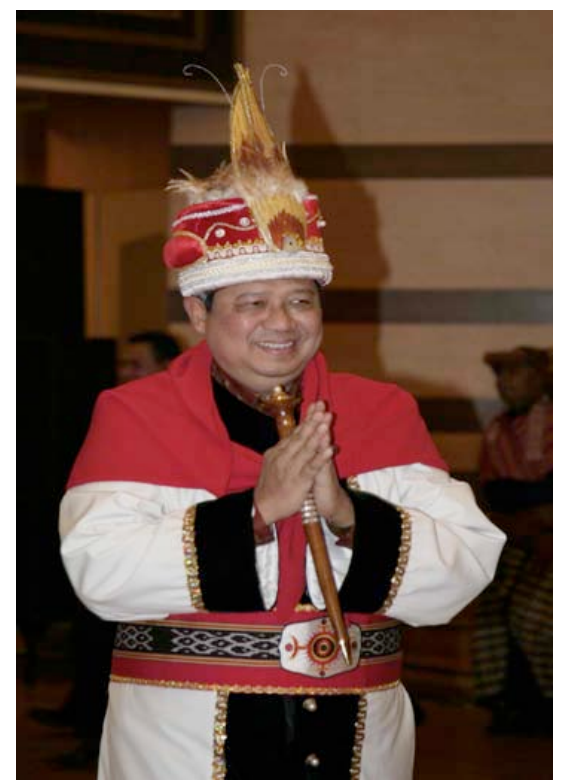

Gambar 3. SBY dianugerahi gelar adat "Upu Latu Rat Maran Siwa Lima" (Raja Besar Maluku). Mengenakan ikat pinggang kain berwarna merah, hitam, kuning, biru dan tongkat emas, menyimbolkan kesiapan pemimpin besar melaksanakaan tugas. Dan kain bahu berwarna merah simbol masyarakat Maluku.

Sebuah penghargaan yang kontroversial

Pemberian penghargaan kepada presiden SBY semakin menunjukkan bahwa kearifan lokal ini baru diterima sebagai konsensus politik yang sifatnya masih birokratis dan elitis, dan belum menjadi konsensus dan komitmen secara sosio-kultural yang diterapkan dengan penuh kesadaran oleh masyarakat di tingkatan akar rumput. Siwa lima masih menjadi sebatas lambang provinsi, tertera sebagai nama museum, tugu, rumah adat, dan penghargaan bagi tamu agung, tapi belum menjadi kearifan yang mengisi lembaran hidup baru bagi masyarakat Ambon pascakonflik. Implementasi siwa lima di tataran akar rumput sangat penting, karena ide-idenya selain untuk menemukan kembali identitas dan tradisi masyarakat Ambon, juga mampu menawarkan semacam inklusivitas atau sikap terbuka, toleran dan akomodatif terhadap pandangan-pandangan yang berbeda dan beragam. Implementasi ini sangat urgen mengingat realitas urban Ambon berubah dengan cepat dan 
kompleks khususnya sejak terjadinya modernisasi, berjubelnya kaum migran dan konflik agama.

\section{Simpulan}

Redefinisi siwa lima sangatlah mendesak, mengingat pendukung kebudayaan di Pulau Ambon sangatlah beragam, terdiri beragam sub etnis dan pengguna bahasa lokal yang diketahui masih aktif sebanyak 117 dari jumlah bahasa lokal yang pernah ada kurang lebih 130-an. Bahasa-bahasa ini diklasifikasikan dalam ranah Austronesian (Soselisa, 1: 2003). Disamping itu, munculnya modernitas semakin memperkuat munculnya polarisasi antara agama Islam dan Kristen yang dipeluk oleh mayoritas masing-masing sub etnis. World view terhadap siwa lima merupakan mediasi terhadap semua keragaman tersebut. Menghidupkan kembali siwa lima adalah sebuah proses pencarian identitas diri, mencari tahu siapa diri orang Ambon sesungguhnya, sehinggga dapat dijadikan sebagai modal sosial untuk menjali persatuan dan kebersamaan.

Siwa lima dianggap sebagai budaya asli orang Maluku, mengingat jauh sebelum orang Maluku mengenal Pancasila dan Indonesia, mereka telah mengenal istilah siwa lima. Kearifan lokal ini menjadi semacam pandangan filosofis dasar untuk membangun organisasi dan struktur sosial yang akan dibangun dalam masyarakat. Bahkan jauh sebelum masa kolonial, pemikiran lokal ini dimanfaatkan sebagai pranata sosial yang menjamin adanya kestabilan pemerintahan.

Permasalahnnya sekarang, hampir semua generasi muda tidak mengenal dengan baik apa itu siwa lima. Beberapa pemuda yang saya wawancarai juga menganggap bahwa konsep siwa lima cenderung hanya menjadi pandangan filosofis semata, tanpa tahu bagaimana harus menjabarkan dan mengimplementasikan ditingkatan praktis. Bukan hanya di kalangan anak muda, dari beberapa obrolan dengan para tetua di Ambon, hampir semua menyesali kerusuhan yang pernah terjadi, dan mereka kini merasa mengkhianati para leluhurnya yang telah bersusah payah menciptakan siwa lima dan pela-gandong. Satu dekade setelah konflik, salah seorang warga senior Ambon, sebut saja, Luhuselani menyesali:

Katong ini su beberapa tabun laeng seng liat laeng, sagu salempeng seng pata dua, ale rasa beta rasa, katong manyanyi saja, tapi katong seng baku sontoh. Sekarang beta su bisa liat laeng, disini beta pung sodara-sodara, disana beta pung sodara-sodara jua.

[Kita ini sudah beberapa tahun tidak saling melihat dengan orang lain, sagu satu lempeng tidak lagi terbagi dua, saya rasa kamu rasa, kita menyanyi saja, tapi kita tidak saling bersentuhan. Sekarang saya sudah bisa melihat orang lain, disini saya punya saudara, disana saya juga punya saudara-saudara.]

Luhuselani berujar dengan mata berkaca-kaca. Tampaknya saat ini ia benar-benar merasakan makna sapa bale batu, batu bale dia, siapa membalik batu, batu akan membalikkan dia. Siapa melupakan adat dan tradisi, adat dan tradisi itulah yang kelak akan membalikkan dia. Ini telah terbukti dengan perang berdarah-darah antar saudara siwa lima sepanjang 
tahun 1999-2003 di seluruh penjuru Maluku. Dapat dikatakan, bahwa mereka adalah orangorang yang telah membalik batu, melupakan tradisi serta kearifan nenek moyang.

\section{Daftar Pustaka}

Abdul Kadir, Hatib. 2009. Bergaya di Kota Konflik. Yogyakarta: Pustaka Pelajar.

Ajawaila, J.W 2009. "Siwalima dalam Perspektif Budaya di Maluku Tengah" dalam Seminar Siwa lima Sebagai Falsafah Hidup Orang Maluku, 19-21 Oktober.

Ar Rijal, Sifar, t.t.. "Hikayat Tanah Hitu" URL: www.anu.edu.au

Basorie, Warief Djajanto. 2005. "Ambon: Conflict, Conciliation, and the Media", Journalismasia.

Benda Beckmann, Franz von. 2007. Social Security between Past and Future: Ambonese Networks of Care and Support. Transaction Publishers.

Chauvel, Richard, Nationalists. 1990. "Soldiers and Separatists: The Ambonese Islands from Colonialism to Revolt, 1880-1950.” Verbandelingen van het Koninklijk Instituut voor Taal-, Land-en Volkenkunde; 143. Leiden: KITLV Press.

Cooley, F. L.. 1968. "Altar and throne in Central Moluccan societies” Practical Anthropology 15: $118-37$.

Bartels, Dieter. 1979. "Politicians and Magicians: Power, Adaptive Strategies an Syncretism in the Central Moluccas" in Gloria Davis (ed.), What is Modern Indonesian Culture? Athens: Ohio University Center for International Studies.

2003. Desember 14, "The Evolution of God in Space Islands: The Converging and Diverging, of Phrotestant Christianity and Islam in the Colonial and Postcolonial Periods". Symposium "Christianity in Indonesia" at the Frobenius Institute of the Johann Wolfgang Goethe University in Frankfurt/Main.

Castells, Manuel. 1997. The Power of Identity. Oxford: Blackwell.

Davidson, Jamie S. dan Henley, David. 2007. The Revival of Tradition in Indonesian Politics. London \& New York: Routledge.

Hobsbawn, Eric dan Ranger, Terence. 1993. The Invention of Tradition. Cambridge: Cambridge University Press.

Hulsbosch, Marianne. 2004. Pointy shoes and pith helmets: dress and identity construction in Ambon from 1850 to 1942. Wollongong: University of Wollongong.

Huliselan, Muh. 2009. "Siwalima dalam Perspektif Budaya di Maluku Tenggara," dalam dalam Seminar Siwa lima Sebagai Falsafah Hidup Orang Maluku, 19-21 Oktober.

Anonim. 2001. "Asia Report Indonesia: Overcoming Murder and Chaos in Maluku” ICG No. 10, 19 December. 